\title{
Research on Anti-oxidant Activity and Hypolipemic Mechanism of Aloes Flavonoids in Mice
}

\author{
Li Nan ${ }^{1, *}$, Ouyang Kehui ${ }^{2, *}$, Cai Jiaoying1, Yang Wuying ${ }^{1}$, Wang Wenjun ${ }^{1, *}$ \\ ${ }^{1}$ Key Lab for Agro-products Processing and Quality Control of Nanchan City, College of Food Science and Engineering, Jiangxi \\ Agricultural University, Nanchang, China \\ ${ }^{2}$ College of Animal Science and Technonlogy, Jiangxi Agricultural University, Nanchang, China \\ *Corresponding author: wwjun9999@sina.com
}

Received July 07, 2014; Revised September 02, 2014; Accepted September 08, 2014

\begin{abstract}
Aloe flavonoids exhibit various biological activities. The aim of this study was conducted to evaluate antioxidant activity and the hypolipemic mechanism of aloe flavonoids in mice. 80 hyperlipidemic mice were divided into 5 groups, each group was oral administrated with water, $4 \mathrm{mg} / \mathrm{kg} \cdot \mathrm{BW}$ simvastatin, 100, 200, 300 $\mathrm{mg} / \mathrm{kg}$.BW aloe flavonoids per day, respectively. Meanwhile, 16 normal mice were used as blank control, and oral administrated with water per day. After 8 weeks intervention, the concentrations of total cholesterol (TC), triglyceride (TG), high-density lipoprotein cholesterol (HDL), total antioxidant capacity (T-AOC) and glutathione peroxidase (GSH-Px) in the adipose and liver tissues were evaluated. Also, hormone-sensitive lipase (HSL), peroxisome proliferator-actived receptor gamma (PPAR- $\gamma$ ), adipose triacylglyceride lipase (ATGL), and fatty acid synthase (FAS) genes expressions in the two tissues were detected by Q-PCR. The results showed that aloe flavonoids could decrease the TC, TG levels in the adipose and liver, while the levels of T-AOC, CAT, GSH-Px were significanly increased when compared to the control group. After treating with aloe flavonoids, the gene expressions of HSL, PPAR $\gamma$ and ATGL expression enhanced, but the gene expression of FAS decreased when compared to the control group. In conclusion, our data showed that aloe flavonoids have potent hypolipemic and antioxidant activities.
\end{abstract}

Keywords: aloe, flavonoids, hypolipemic mechanism, gene expression, mice

Cite This Article: Li Nan, Ouyang Kehui, Cai Jiaoying, Yang Wuying, and Wang Wenjun, "Research on Anti-oxidant Activity and Hypolipemic Mechanism of Aloes Flavonoids in Mice." Journal of Food and Nutrition Research, vol. 2, no. 9 (2014): 601-607. doi: 10.12691/jfnr-2-9-12.

\section{Introduction}

Aloe is one of the most widely consumed plants in tropical and subtropical areas. It has been reported that aloe has various biological activities, which was attributed to the high flavonoids content. These compounds are classified into different subclasses, and for the major subclasses of flavonols (quercetin and rutin) and catechins, comprehensive data on their concerntrations in food are available [1]. In addition to their antioxidant effects, flavonoids have antiviral, antiallergic, anti-inflammatory and antitumor activities [2,3].

In recent years, hyperlipidemia is growing at a rapid rate throughout the world, which increase the risk of cardiovascular diseases, fatty liver, and carcinogenesis [4]. It has been reported that a variety of factors, including genetic abnormalities, diabetes meuitus, obesity and renal failure, are involved in the development of hyperlipidemia [5]. Excessive quantities or improper types of lipid-intake may result in hyperlipidemia which is characterized by an abnormal elevation in one or more of the serum lipids such as total cholesterol (TC), triglycerides (TG) and high-density lipoprotein-cholesterol (HDL-C).
Hyperlipidemia is considered to be a major risk factor for cardiovascular disease which has been an epidemic public and economic problem [6].

Recently, interests are focusing on the use of nonvitamin antioxidants such as flavonoids in reducing the negative effect of oxidative stress and free radicals in diabetic patients [7]. Flavonoids and flavonoid-rich extracts have been implicated as beneficial agents in a multitude of disease states [8]. Therefore, searching for the hypolipemic and antioxidative mechanisms at the molecular level are essential to overcome these problems. It is reported that lipid metabolism is a complex procedure, and many enzymes and factors are involved in it. Fat stored in adipose tissue is mobilized by the hydrolytic action of lipases, which degrade triglycerides (TG) and release free fatty acids (FFA) and glycerol into the circulation, and there are two major enzymes involved in the breakdown of triglycerides in adipose tissue, they are ATGL and HSL [9]. ATGL is the rate-limiting enzyme of lipolysis that hydrolyzes triglycerides to diglycerides, and it may determine the maximal rate for fatty acid mobilization, whereas HSL is a multifunctional enzyme that has a broad substrate specificity, with a preference for diglycerides [9]. 
The aim of the present study was to evaluate the effects of aloe flavonoids extract on hypolipemic effect, antioxidant activity, and the regulation of adipose tissue and liver tissue gene expression in high-fat diet-induced hyperlipidemic mice.

\section{Materials and Methods}

\subsection{Plant Material and Extraction}

Flavonoids were prepared with ultrasonic extraction, freeze-drying, vaccum concerntration and polyamide polymer purification from the aloe powder. Then the Aloe flavonoids extract and pure water were administrated by intragastric gavage, to guarantee total ingestion. The animals were treated for 8 weeks to ensure the effect of the experiment.

\subsection{Animals and Treatments}

Ninty-six female Kunming mice (Bought from Medical College of Nanchang University, certified No. 021-9601) weighted 25-30 g were used in this study. The animals were maintained at room temperature $\left(23 \pm 2^{\circ} \mathrm{C}\right)$ with a 12 $\mathrm{h} / 12 \mathrm{~h}$ light-dark cycle and housed in some cages. The animals were fed freely one week, and had free access to standard mice chow and water. For the induction of heperlipidemia, 80 animals were fed with a high-fat diet (10\% cholesterol, 89\% larb oil and 1\% cholic acid sodium) for 4 weeks. Meanwhile, 16 normal mice continual fed with basal diet as the blank control group, after 4 weeks, determine the TC, TG, HDL-C levels in the serum of the overnight fasted mice. In comparison to TC level of the blank control group, there was a significant difference between the control group and the high-fat diet group. Then the high-fat diet animals were randomly divided into 5 groups according to the TC levels: model group (administrated with $1 \mathrm{ml}$ water per day), positive group (simvastain group, $4 \mathrm{mg} / \mathrm{Kg} \cdot \mathrm{BW} / \mathrm{d}$ ), and the remaining three groups administrated with different dosages of aloe flavonoids extracts $(100 \mathrm{mg} / \mathrm{Kg} \cdot \mathrm{BW} / \mathrm{d}, 200 \mathrm{mg} / \mathrm{Kg} \cdot \mathrm{BW} / \mathrm{d}$, $300 \mathrm{mg} / \mathrm{Kg} \cdot \mathrm{BW} / \mathrm{d})$. All test and reference materials were orally administered daily beginning on day 7 after the initiation of the high-fat diet treatment while the control group mice were continuously supplied with a normal diet throughout the experiment. At the end of the experiment, all mice were anesthesia, the adipose and liver tissues were dissected and stored at $-80^{\circ} \mathrm{C}$ until they were analyzed. Approval of this experiment was obtained from the Institution Animal Ethics Committee of Jiangxi Agricultural University.

\subsection{Biochemical Analysis}

Levels of total cholesterol(TC), triglyceride(TG), and high-density lipoprotein cholesterol in adipose and liver tissue were determined using the reagent kit (Biosino Biotechnology and Science Inc). Total antioxidant capacity (T-AOC) and glutathione peroxidase (GSH-Px) levels in adipose and liver tissues were determined using the reagent kit (Nanjing Jiancheng Bio- engineering Institute).

\subsection{RNA Extraction and Q-PCR}

RNA isolation and first strand cDNA synthesis: Total hepatic and adipose RNA were isolated from small pieces of livers and adipose tissues (50-100 mg) using Trizol (Promega company). RNA was reverse-transcribed using the Easyscript (TransGen Biotech, China). 50 ng-5 $\mu \mathrm{g}$ of total RNA was mixed with $10 \mu \mathrm{L} 2 \times \mathrm{ES}$ Reaction Mix, 1 $\mu \mathrm{L}$ Anchored Oligo (dT) $18(0.5 \mu \mathrm{g} / \mu \mathrm{L}), 1 \mu \mathrm{L}$ Easyscript TM RT/RI Enzyme Mix and nuclease-free water in a total volume of $20 \mu \mathrm{L}$. The mixture was incubated for $42 \mathrm{~min}$ and heated at $80^{\circ} \mathrm{C}$ for $5 \mathrm{~min}$. The cDNA was stored at $20^{\circ} \mathrm{C}$ until used for quantitative PCR.

Quantification of mRNA transcript was performed using qPCR Master mix Plus Kit for SYBR Green (TaKaRa Biotechnology, China) with the gene-specific primer on the Bio-Rad CFX96 real-time PCR system. Relative transcript quantities (RQ) were calculated from the equation $R Q=2^{-\triangle \triangle \mathrm{CT}}$ (fold) according to the $\triangle \triangle \mathrm{CT}$ method [10]. In this system, all reactions were run in glass capillaries with a total volume of $25 \mu \mathrm{L}$. The reaction mixture consisted of $1 \mu \mathrm{L}$ cDNA, $0.5 \mu \mathrm{L}$ FP $(10 \mu \mathrm{M}), 0.5$ $\mu \mathrm{L}$ RP(10 $\mu \mathrm{M})$ (Table 1), $12.5 \mu \mathrm{L} 2 \times$ Taq PCR Master Mix and dd $\mathrm{H}_{2} \mathrm{O} 10.5 \mu \mathrm{L}$. The PCR consisted of the following steps: $50^{\circ} \mathrm{C}$ for 2 min to prevent carry over of DNA and a denaturation step for $2 \mathrm{~min}$ at $95^{\circ} \mathrm{C}$, followed by 31-34 cycles (HSL, PPAR $\gamma$, FAS 31 cycles, ATGL 34 cycles and $G A P D H 32$ cycles) of denaturation at $94^{\circ} \mathrm{C}$ for $30 \mathrm{~s}$, annealing for $15 \mathrm{~s}$ at $61^{\circ} \mathrm{C}$, and primer extension at $72^{\circ} \mathrm{C}$ for 40 s. HSL, PPAR $\gamma, A T G L, F A S$ expression were examined and normalized to constitutive gene (GAPDH) (Table 1).

Table 1. PCR primer sequence and product size

\begin{tabular}{|c|c|c|c|}
\hline Target gene & GenBank accession No. & Primer sequenee & PCR product \\
\hline \multirow{2}{*}{ HSL } & \multirow{2}{*}{ ref|NT_039413.7 } & F: 5'-ACGGCGGCTG TCTAATGTCT-3 ' & \multirow{2}{*}{227 bp } \\
\hline & & R: 5'-GGCTGGCACGGAAGAAGATA -3 ' & \\
\hline \multirow{2}{*}{ PPAR $\gamma$} & \multirow{2}{*}{ ref|NT_039413.7 } & F: 5'-CССТTTACCACACCAGATTTCTCCAG-3 ' & \multirow{2}{*}{ 253bp } \\
\hline & & R: 5'-CTGATGCTTTATGCACACAGACTCGG-3 ' & \\
\hline \multirow{2}{*}{ ATGL } & \multirow{2}{*}{ ref|NT_039687.7 } & F: 5'-СТСАТТССТССТАСССТССАА-3 & \multirow{2}{*}{ 489bp } \\
\hline & & R: 5'-CGTCTGCTCTTTCATCCACC-3 & \\
\hline \multirow{2}{*}{ FAS } & \multirow{2}{*}{ ref|NT_039624.7 } & F: 5'-CTCGTGTGAACATGGAACCCT-3 & \multirow{2}{*}{407 bp } \\
\hline & & R: 5'-TCTTCAGCAATTCTCGGGATG-3 & \\
\hline \multirow{2}{*}{ GAPDH } & \multirow{2}{*}{ ref|NT_039625.7 } & F: 5'-CATCACCATCTTCCAGGAGCG-3 & \multirow{2}{*}{308 bp } \\
\hline & & R: 5'-GAGGGGCCATCCACAGTCTTC-3 & \\
\hline
\end{tabular}




\subsection{Statistical Analysis}

The results were expressed as means \pm SEM(standard error of the mean). Comparisons among groups of data were done using one-way ANOVA followed by the Dunnett Multiple Comparisons test. An associated probability ( $P$ value of $5 \%$ ) was considered significant. Statistical analysis was performed using SPSS 17.0 professional version.

\section{Results}

作

\begin{tabular}{ccccc}
\multicolumn{5}{c}{ Table 2. Effect of Aloe flavonoids on TC, TG and HDL-C in liver of mice } \\
\hline Group & dose $(\mathrm{mg} / \mathrm{kg})$ & TC level $(\mathrm{mmol} / \mathrm{l})$ & TG level $(\mathrm{mmol} / \mathrm{l})$ & HDL-C level $(\mathrm{mmol} / \mathrm{l})$ \\
\hline Model & - & $1.90 \pm 0.13^{\mathrm{a}}$ & $3.18 \pm 0.26^{\mathrm{a}}$ & $0.14 \pm 0.03^{\mathrm{c}}$ \\
Positive & 4 & $1.38 \pm 0.08^{\mathrm{cd}}$ & $2.43 \pm 0.1122^{\mathrm{b}}$ & $0.24 \pm 0.03^{\mathrm{bc}}$ \\
LDG & 100 & $1.69 \pm 0.21^{\mathrm{ab}}$ & $2.65 \pm 0.39^{\mathrm{ab}}$ & $0.24 \pm 0.04^{\mathrm{bc}}$ \\
MDG & 200 & $1.49 \pm 0.14^{\mathrm{bc}}$ & $2.65 \pm 0.13^{\mathrm{ab}}$ & $0.24 \pm 0.02^{\mathrm{bc}}$ \\
HDG & 300 & $1.16 \pm 0.11^{\mathrm{cd}}$ & $2.33 \pm 0.17^{\mathrm{b}}$ & $0.28 \pm 0.03^{\mathrm{ab}}$ \\
Control & - & $0.90 \pm 0.08^{\mathrm{d}}$ & $1.93 \pm 0.25^{\mathrm{b}}$ & $0.37 \pm 0.05^{\mathrm{a}}$ \\
\hline Note: & - & & & \\
\end{tabular}

Table 3. Effect of Aloe flavonoids on TC、TG and HDL-C in adipose of mice

\begin{tabular}{cccc}
\hline Group & dose $(\mathrm{mg} / \mathrm{kg})$ & TC level $(\mathrm{mmol} / \mathrm{l})$ & TG level $(\mathrm{mmol} / \mathrm{l})$ \\
\hline Model & - & $1.59 \pm 0.24^{\mathrm{A}}$ & $17.96 \pm 1.91^{\mathrm{A}}$ \\
Positive & 4 & $0.11 \pm 0.03^{\mathrm{B}}$ & $16.48 \pm 4.51^{\mathrm{AB}}$ \\
LDG & 100 & $1.06 \pm 0.12^{\mathrm{BC}}$ & $16.87 \pm 2.84^{\mathrm{AB}}$ \\
MDG & 200 & $0.90 \pm 0.11^{\mathrm{BC}}$ & $0.11 \pm 0.01$ \\
HDG & 300 & $0.53 \pm 0.14^{\mathrm{CD}}$ & $0.15 \pm 0.02$ \\
Control & - & $0.42 \pm 0.06^{\mathrm{D}}$ & $0.21 \pm 0.04$ \\
\end{tabular}

Note: The means with different letter in the same row is significantly different $(P<0.01)$

\subsection{T-AOC and GSH-Px Levels Activities in Liver and Adipose Tissue}

The effects of intragastric gavage of aloe flavonoids extract on liver and adipose antioxidant status are presented in Table 4. A significant decrease in T-AOC and

\subsection{TC, TG and HDL-C Levels in Adipose and Liver Tissue}

The results showed that the TC and TG concentrations in the liver and adipose tissue were significantly increased $(p<0.01)$, whereas liver HDL-C level was decreased in the untreated model control mice when compared with blank control mice $(p<0.01)$ (data not shown). However, after treatment with the Aloe flavonoids extract, the alteration in hyperlipidemia was varied attenuated as evidenced by decreased TG, TC levels and by increased HDL-C concentration in Aloe flavonoids intervention groups $(p<0.01)$ in a different dose dependent manner (Table 2 and Table 3).
GSH-Px activities $(p<0.01)$ were found in the livers and adipose of untreated model control mice relative to normal mice. Treatment with different doses of aloe flavonoids extract reversed this biochemical parameter significantly towards normal level aloe flavonoids intervention groups $(p<0.01)$ in a different dose dependent manner (Table 4).

Table 4. Effect of $\boldsymbol{A F}$ on T-AOC and GSH-Px in liver and adipose of mice

\begin{tabular}{|c|c|c|c|c|c|}
\hline Group & Dose (mg/kg) & Liver T-AOC (U/ mgprot) & Liver GSH-Px(U) & Adipose T-AOC (U/ mgprot) & Adipose GSH-Px (U) \\
\hline Model & - & $0.17 \pm 0.02^{\mathrm{C}}$ & $47.32 \pm 4.75^{\mathrm{C}}$ & $0.09 \pm 0.01^{\mathrm{C}}$ & $37.34 \pm 6.87^{\mathrm{D}}$ \\
\hline Positive & 4 & $0.21 \pm 0.03^{\mathrm{BC}}$ & $59.54 \pm 8.56^{\mathrm{BC}}$ & $0.16 \pm 0.02^{\mathrm{BC}}$ & $53.25 \pm 9.59^{\mathrm{CD}}$ \\
\hline LDG & 100 & $0.20 \pm 0.02^{\mathrm{BC}}$ & $47.98 \pm 6.15^{\mathrm{C}}$ & $0.15 \pm 0.01^{\mathrm{BC}}$ & $42.29 \pm 5.14^{\mathrm{CD}}$ \\
\hline MDG & 200 & $0.20 \pm 0.02^{\mathrm{BC}}$ & $70.96 \pm 2.90^{\mathrm{ABC}}$ & $0.17 \pm 0.02^{\mathrm{BC}}$ & $96.18 \pm 26.92^{\mathrm{BCD}}$ \\
\hline HDG & 300 & $0.32 \pm 0.02^{\mathrm{A}}$ & $98.99 \pm 8.72^{\mathrm{A}}$ & $0.37 \pm 0.06^{\mathrm{A}}$ & $140.38 \pm 35.97^{\mathrm{AB}}$ \\
\hline Control & - & $0.33 \pm 0.03^{\mathrm{A}}$ & $102.34 \pm 9.22^{\mathrm{A}}$ & $0.39 \pm 0.04^{\mathrm{A}}$ & $185.84 \pm 9.21^{\mathrm{A}}$ \\
\hline
\end{tabular}

Note: The means with different letter in the same row is significantly different $(P<0.01)$

\subsection{Effects of aloe Flavonoids on the Expression of HSL, ATGL, PPAR $\gamma$ and FAS mRNA in the Liver and Adipose Tissues}

The mRNA expression levels of HSL, ATGL, PPAR and FAS were determined in liver and adipose tissues isolated from the previously described animals. In liver tissue, the high-fat diet did not affect the expression of HSL, ATGL, PPAR $\gamma$ and FAS (Table 5). In addition, with the treatment of aloe flavonoids extract interfere, no significant effect on the HSL, ATGL, PPAR $\gamma$ and FAS mRNA expression levels (Table 5). In adipose tissue, the high-fat diet caused an upregulation of the FAS gene, significantly down regulated the expression of HSL (Table 6). After treatment with aloe flavonoids extract, the expression levels of HSL, ATGL and PPAR $\gamma$ were increased. On the other hand, the FAS gene expression levels was significantly reduced (Table 6).

Table 5. The results of relative optical density of $H S L, P P A R \gamma, A T G L$ and FAS mRNA in liver

\begin{tabular}{cccc}
\hline Group & $\begin{array}{c}\text { HSL mRNA } \\
\text { relative optical density }\end{array}$ & $\begin{array}{c}\text { PPAR mRNA } \\
\text { relative optical density }\end{array}$ & $\begin{array}{c}\text { ATGL mRNA } \\
\text { relative optical density }\end{array}$ \\
\hline Model & $1.34 \pm 0.18$ & $0.81 \pm 0.01$ & $1.03 \pm 0.29$ \\
relative optical density
\end{tabular}


Table 6. The results of relative optical density of $H S L, P P A R \gamma, A T G L$ and FAS mRNA in adipose

\begin{tabular}{|c|c|c|c|c|}
\hline Group & $\begin{array}{c}H S L \text { mRNA } \\
\text { relative optical density }\end{array}$ & $\begin{array}{c}P P A R \gamma \text { mRNA } \\
\text { relative optical density }\end{array}$ & $\begin{array}{l}\text { ATGL mRNA } \\
\text { relative optical density }\end{array}$ & $\begin{array}{l}\text { FAS mRNA } \\
\text { relative optical density }\end{array}$ \\
\hline Model & $0.64 \pm 0.03 \dagger$ & $1.08 \pm 0.12$ & $0.78 \pm 0.19$ & $1.51 \pm 0.54$ \\
\hline Positive & $0.71 \pm 0.02 * * * \dagger$ & $0.92 \pm 0.16 a$ & $0.90 \pm 0.05$ & $1.09 \pm 0.12$ \\
\hline MDG & $0.78 \pm 0.03^{* *}$ & $1.11 \pm 0.16$ & $1.13 \pm 0.31 *$ & $0.97 \pm 0.11^{* *}$ \\
\hline HDG & $1.36 \pm 0.20 * * *$ & $1.50 \pm 0.01 b$ & $1.29 \pm 0.13^{* * b}$ & $0.87 \pm 0.09 * *$ \\
\hline Control & $1.00 \pm 0.02 *$ & $1.00 \pm 0.13$ & $1.00 \pm 0.10$ & $1.00 \pm 0.0 *$ \\
\hline
\end{tabular}

Note: $H S L: \dagger \mathrm{P}<0.05$ and $\ddagger \mathrm{P}<0.01$, when compared to control group; $* \mathrm{P}<0.05$, $* * \mathrm{P}<0.01$ and $* * * \mathrm{P}<0.005$, when compared to model group;

$P P A R \gamma: \mathrm{P}<0.05$ and $\mathrm{P}<0.01$, the different letter means multiple comparisons among the treatment groups;

ATGL: $\dagger \mathrm{P}<0.05$ and $\ddagger \mathrm{P}<0.01$, when compared to control group; $* \mathrm{P}<0.05$ and $* * \mathrm{P}<0.01$, when compared to model group; $\mathrm{P}<0.05$ and $\mathrm{P}<0.01$, the different letter means multiple comparisons among the treatment groups; FAS: $* \mathrm{P}<0.05$ and $* * \mathrm{P}<0.01$, when compared to model group

\section{Discussion}

Flavonoids is a well-known group of natural compounds, and more than 6000 different types have been identified, and surely this number will increase [11]. The flavonoids are naturally occurring plant polyphenols found in abundance in fruits and vegetables, and they are considered as a promising source for drug development, as they have been implicated as beneficial agents in a multitude of disease states [8], such as anticancer, antioxidant, and anti-inflammatory [12,13]. What is more, most flavonoids show suppressive effects on adipogenesis [14].

Several animals and human studies have confirmed the hypercholesterolemic properties of saturated fatty acids and cholesterol which include increasing total cholesterol and altering lipoprotein pattern. Cholesterol feeding has been often used to elevate tissue cholesterol levels to assess hypercholesterolemia-related metabolic disturbances in different animal models [15]. In the present study, we confirmed that keeping the animal on high-fat diet significantly increased the TC, TG and decrease the HDL-C level in liver and adipose tissues compared to the mice with normal diet when high-fat diet was coadministered with aloe flavonoids extracts, the elevated levels of TC and TG condition has shown considerable decline, otherwise, the HDL-C level was increased. There was significant elevation in liver and adipose HDL-C in Aloe flavonvoids treated mice as compared to high-fat diet-induced mice, thus indicating the efficacy of Aloe flavonvoids extract in preventing the elevation seen in various components of lipid profile under experimentally induced hyperlipidemia.

Previous data showed that citrus peel extracts, riched in pectins and flavonoids, cause lowering of cholesterol levels by modulating hepatic HMG-CoA levels, possibly by binding bile acids and increasing the turnover rate of blood and liver cholesterol [16]. Mollace et al (2011) reported that bergamot polyphenols flavonoid oral supplements contribute to lowering plasma cholesterol and lipids in a rat model of diet-induced hyperlipemia and in patients, in a range of potency comparable with low dose statins [17]. Kobori et al (2011) reported that chronic dietary intake of quercetin reduced body weight gain, as well as visceral and liver fat accumulation, and improved systemic parameters related to metabolic syndrome (hyperglycemia, hyperinsulinemia and dyslipidemia), probably by decreasing oxidative stress and increasing PPAR $\gamma$ expression [18].

From obtained result it was observed that flavonvoids obtained from aloe showed higher anti-hyperlipidemic ability in lowing the levels of TC and TG and in highing the levels of HDL-C in liver and adipose tissues. Its antihyperlipidemic effect was also superior to a commercially available drug (positive control). These results indicated that the aloe flavonoids might play an important role in modulate the lipid metabolism, although whose mechanisms remain under study.

Oxidative stress is currently suggested as a mechanism underlying hyperlipemia and it has been implicated in the causation of ailments such as diabetes, cardiovascular, cancer and aging, etc. Antioxidant substrates from plants may offer resistance against the oxidative stress by scavenging free radicals, inhibiting lipid peroxidation [19]. There is a variety of evidence indicating that antioxidant enzyme activities are lower in animals fed with high-fat diet [20], which can also degrade antioxidant enzyme defenses, thereby allowing reactive oxygen species to damage cells and tissues. In the present study, oxidative stress occurred in mice fed with high-fat diet as evident by elevated levels of GSH-Px, which can catalyzes the reduction of $\mathrm{H}_{2} \mathrm{O}_{2}$ and $\mathrm{O}_{2}$ at the expense of $\mathrm{GSH}$ [21], it decreased antioxidant activities in liver and adipose tissues, suggesting the high-fat diet can increased lipid peroxidation and oxidative stress. Flavonoids are a large group of ubiquitous molecules and possess antioxidant activities, their planar structure, number and position of their hydroxyl groups, are crucial for free-radical scavenger capacities, and the inhibition of free radical producing enzymes [22].

In this study, we observed a significantly decrease TAOC and GSH-Px activities in liver and adipose in highfat model group compared with the control group. Administration of Aloe flavonoids significantly enhanced T-AOC and GSH-Px activities in liver and adipose in Aloe flavonoids-treated mice compared to the control mice. This suggested that Aloe flavonoids treatment had antioxidant effect. Our data indicate that Aloe flavonoids may reduce the oxidative stress in experimental animals, resulting in a lower lipid peroxidation in liver and adipose tissues. In summary, an high-fat diet caused heperlipidemic and oxidative injury occurred in mice fed with high-fat diet, as did elevate variety of indexes and oxidative stress in liver and adipose tissues. Our result in accordance with the recently study that extracts of the leaves of Meyna spinosa contain high levels of flavonoids, and possess significant antioxidant activities [23]. Arora et al (1998) found that flavonoids displayed higher antioxidant capacity against metal-ion-induced peroxidation than peroxyl-radical-induced peroxidation [24].

It has been shown that in mice, ATGL is predominantly expressed in white and brown adipose tissue. Lower enzyme levels were found in testis, cardiac and skeletal 
muscle, and is downregulated in mouse models of obesity [25]. ATGL-deficient mice have higher accumulation of neutral lipids in most tiuuses, show a two-fold increase in whole body fat mass and contain enlarged adipose fat depots [26]. It also demonstrated that ATGL is essential for the control of normal weight because overexpression of the ATGL homolog depleted fat stores and caused obesity [27].

Hormone-sensitive lipase $(H S L)$ is an intracellular neutral lipase, which is capable of hydrolyzing TAGs, DAGs, MAGs and cholesteryl esters (CE). Holm et al (1988) examined the HSL mRNA levels in different tissues of the rat, and found that this mRNA was abundant in the fatty tissue and other cholesterol producing tissues, while it was scarce in the cardiac and skeletal muscles [28]. It is demonstrated that HSL deficiency in mice markedly affected the metabolism of TG-rich lipoproteins by the coordinate down-regulation of very low density fatty acids synthesis and up-regulation of lipoprotein lipase in muscle and white adipose tissue [26]. Reid et al (2008) showed that hepatic overexpression of HSL can promote fatty acid oxidation, stimulate direct release of free fatty acid, and ameliorate hepatic steatosis [29]. In our study, dietary administration of Aloe flavonoids led to a significant increase in ATGL and HSL mRNA level in adipose tissue (Table 6). Since the ATGL and HSL are key enzymes involved in adipose tissue TG catabolism, and both lipases have the ability to hydrolyze triglycerides, this results suggests that the action of Aloe flavonoids to reduce lipid and have effect on anti-oxidant activity in hyperlipidemic mice involved inhibiting lipogenesis besides stimulating lipolysis. Xie et al (2009) reported that flavanone had the function of depressing the concentration of blood-fat, it co-adjusted lipid metabolism of animal by regulating the transcription expression of FAS, HSL, TGH and SREBP-1c, especially HSL and SREBP-1C transcription level [30].

Fatty acid synthase (FAS) plays a central role in denove lipogenesis by converting acetyl-CoA and malont-CoA into the final end product palmitate, it is highly expressed in tissues like liver, adipose and lactating mammary glands. In normal physiological state, nutritional factors such as high-fat diet and hormone could regulate the enzyme activity and gene expression of the FAS [31]. FAS gene promoter activities were 4 to 6-fold higher in adipocytes of obese rats than in those of non-obese rats. It has been reported that FAS gene expression in human adipose tissue is associated with obesity and type 2 diabetes [32]. Chakravarthy et al (2009) have reported that a low level of FAS could protect mice from diet-induced obesity [33]. The level of FAS in the present study was lower in aloe flavonoids treatment groups than in model group, this is in accordance with previous studies demonstrating that Nelumbo nucifera leaf flavonoid-rich extract targets lipid-regulated enzymes and may be effective in attenuating body lipid accumulation and preventing obesity [34]. But in the liver, the FAS mRNA expression shown no significant decrease when compared with the model group. The plausible reason for this maybe insufficient amounts of fatty acids were supplied from high-fat dietary [35]. Additionally, which regulates the expression of such adipogenic gene as FAS, PPAR- $\gamma$ has been reported as a key transcriptional factor for lipid accumulation [36].
Peroxisome proliferator-activated receptor $\gamma(P P A R \gamma)$, a major nuclear receptor transcription factor for adipogenesis and lipogenesis, is predominantly expressed in adipose tissues and to a lesser extent in many tissues including liver [37]. Many herbal or natural medicines, that act as modulators of PPARs, have been reported to block intracellular lipid accumulation and lipogenesis and to improve insulin resistance [38]. Citrus flavonoids have been shown to inhibit adipogenesis and to decrease adiposity which can be explained in part by regulating the PPAR expression levels both in vivo and in vitro [38,39]. The result in the present study showed that the expression amount of PPAR $\gamma$ in white adipose tissue in the high doses of aloe flavonoids treated group(HDG) significantly increased as compared with what in the positive group, indicating that normal expression of $P P A R \gamma$ in adipose tissue was critical for prevention of blood lipid levels in hyperlipidemia, this result consistent with previous findings that suppressing $P P A R \gamma$-activity can inhibit adipocyte differentiation in vitro [40], and other result showed that citrus polymethoxylated flavonoids improve lipid and glucose homeostasis through regulating the expression of $P P A R \alpha$ and PPAR [41]. Although compared with the model group, the $P P A R \gamma$ mRNA expression in the Aloe flavonoids treatment groups were not significantly increased, it still showed an increase tendency in our study, and the high dose Aloe flavonoids have the better effect on the gene of PPAR . The result indicated that the Aloe flavonoids could partially restore expression of PPAR $\gamma$ mRNA in white adipose tissue of the model mice and it can work on hyperlipidemia.

\section{Conclusions}

In our experiment, Aloe flavonoids were found to be very effective for hypolipemic and antioxidant activity via up-regulating the HSL, ATGL, PPAR , and downregulating the FAS mRNA expression in adipose tissue. As such, these coordinated responses of the Aloe flavonoids supplement seemed to play an important role in regulating the lipid and oxidative metabolism in hyperlipidemic mice. Accordingly, the different dose of Aloe flavonoids extract exhibited the different impact in the hyperlipidemia and antioxidant, moreover, the high dose of Aloe flavonoid extract shown the more effective function. Thus, further studies are required to determine the dose-related changes associated with Aloe flavonoids and it's concrete molecular mechanism on lipid disease and other diseases.

\section{Acknowledgments}

The financial support of the Jiangxi Provincial Education Development is gratefully acknowledged (KJLD13027, GJJ13281).

\section{Reference}

[1] Arts IC, Hollman PC. (2005) Polyphenol and disease risk in epidemiologic studies. American Journal of Clinical Nutrition, 81 (1 suppl), 317s-325s. 
[2] Middleton E. (1998) Effect of plant flavonoids on immune and inflammatory cell function. Advances in Experimental Medicine and Biology, 439, 175-182.

[3] Lambert JD, Hong J, Yang GY, Liao J, Yang CS. (2005) Inhibition of carcinogenesis by polyphenols: evidence from laboratory investigations. American Journal of Clinical Nutrition, 81, 284s-291s.

[4] Woo MN, Bok SH, Choi MS. (2009) Hypolipidemic and body fatlowering effects of fatclean in rats fed a high-fat diet. Food and Chemical Toxicology, 47, 2076-2082.

[5] LeRoith D, Novosyadlyy R, Gallagher EJ, Lann D, Vijayakumar A, Yakar S. (2008) Obesity and type 2 diabetes are associated with an increased risk of developing cancer and a worse prognosis; epidemiological and mechanistic evidence. Experimental and Clinical Endocrinology \& Diabetes, 116 (suppl 1), s4-s6.

[6] Bulur H, Ozdemirler G, Oz B, Toker G, Ozturk M, Vysal M. (1995) High cholesterol diet supplemented with sunflower seed oil but not olive oil stimulates lipid peroxidation in plasma, liver, and aorta of rats. Journal of Nutritional Biochemistry, 6, 547-550

[7] Asgary S, Naderi GA, Zadegan N S, Vakili R. (2002) The inhibitory effects of pure flavonoids on in vitro protein glycosylation. Journal of Herbal Pharmacotherapy, 2, 47-55.

[8] Havsteen BH. (2002) The biochemistry and medical significance of the flavonoids. Pharmacology \& Therapeutics, 96, 67-202

[9] Lass A, Zimmermann R, Oberer M, Zechner R. (2011) Lipolysis-a highly regulated multi-enzyme complex mediates the catabolism of cellular fat stores. Progress in Lipid Research, 50, 14-27

[10] Livak KJ, Schmittgen TD. (2001) Analysis of relative gene expression data using real-time quantitative PCR and the 2-[delta] [delta] CT-method. Methods, 25, 402-408.

[11] Ferrer J, Austin M, Stewart CJ, Noel J. (2008) Structure and function of enzymes involved in the biosynthesis of phenylpropanoids. Plant physiology and Biochemistry, 46, 356370.

[12] Pandey KB, Rizvi SI. (2009) Plant polyphenols as dietary antioxidants in human health and disease. Oxidative and Medicin Cellular Longevity, 2, 270-278.

[13] Rathee P, Chaudhary H, Rathee S, Rathee D, Kumar V, Kohli K. (2009) Mechanism of action of flavonoids as anti-inflammatory agents: a review. Inflammation \& Allergy Drug Targets, 8, 229235.

[14] Andersen C, Rayalam S, Della-Fera MA, Baile CA. (2010) Phytochemicals and adipogenesis. Biofactors, 36, 415-422

[15] Zulet MA, Barber A, Garcin H, Higueret P, Martínez JA. (1999) Alterations in carbohydrate and lipid metabolism induced by a diet rich in coconut oil and cholesterol in a rat model. Journal of The American College Nutrtion. 18 (1), 36-42.

[16] Bok SH, Lee SH, Park YB, Bae KH, Son KH, Jeong TS, Choi MS. (1999) Plasma and hepatic cholesterol and hepatic activities of 3hydroxy-3-methyl-glutary-CoA reductase and acyl CoA: cholesterol transferase are lower in rats fed citrus peel extract or a mixture of citrus bioflavonoids. The Journal of Nutrition, 129, $1182-1185$.

[17] Mollace V, Sacco I, Janda E, Malara C, Ventrice D, Colica C, Visalli V, Muscoli S, Ragusa S, Muscoli C, Rotiroti D, Romeo F. (2011) Hypolipemic and hypoglycaemic activity of bergamot polyphenols: From animal models to human studies. Fitoterapia, 82, 309-316.

[18] Kobori M, Masumoto S, Akimoto Y, Oike H. (2011) Chronic dietary intake of quercetin alleviates hepatic fat accumulation associated with consumption of a Western-style diet in C57/BL6J mice. Molecular Nutrition \& Food Research, 55, 530-540.

[19] Karou D, Dicko MH, Simpore J, Traore AS. (2005) Antioxidant and antibacterial activities of polyphenols from ethnomedicinal plants of Burkina Faso. African Journal of Biotechnology, 4 (8), 823-828.

[20] Malheiros RD, Moraes VMB, Collin A, Janssens GPJ, Decuypere E, Buyse J. (2003) Dietary macronutrients, endocrine functioning and intermediary metabolism in broiler chickens:pair wise substitutions between protein, fat and carbohydrate. Nutrition Research, 23 (4), 567-578.

[21] Olsvik PA, Kristensen T, Waagbø R, Rosseland BO, Tollefsen KE, Baeverfjord G, Berntssen MH. (2005) mRNA expression of antioxidant enzymes (SOD, CAT and GSH-Px) and lipid peroxidative stress in liver of Atlantic salmon (Salmo salar) exposed to hyperoxic water during smoltification. Comparative Biochemistry and Physiology. Toxicology \& Pharmacology, 141 (3), 314-323.
[22] Philips A, Philip S, Arul V, Padmakeerthiga B, Renju V, Santha S, Sethupathy S. (2010) Free radical scavenging activity of leaf extracts of Indigofera aspalathoides-an in vitro analysis. Indian Journal of Pharmaceutical Education and Research, 45 (4), 310316.

[23] Sen S, De B, Devanna N, Chakraborty R. (2013) Total phenolic, total flavonoid content, and antioxidant capacity of the leaves of Meyna spinosa Roxb, an Indian medicinal plant. Chinese Journal of Natural Medicines, 11 (2), 0149-0157.

[24] Arora A, Nair MG, Strasburg GM. (1998) Structure-activity relationships for antioxidant activities of a series of flavonoids in a liposomal system. Free Radiccal Biology \& Medicine, 24, 13551363.

[25] Zimmermann R, Strauss JG, Haemmerle G, Schoiswohl G, Birner Gruenberger R, Riederer M, Lass A, Neuberger G, Eisenhaber F, Hermetter A, Zechner R. (2004) Fat mobilization in adipose tissue is promoted by adipose triglyceride lipase. Science, 306, 13831386.

[26] Haemmerle G, Zimmermann R, Hayn M, Theussl C, Waeg G, Wagner EF, Sattler W, Margin TM, Zechner R. (2002) Hormonesensitive lipase deficiency in mice causes diglyceride accumulation in adipose tissue, muscle and testis. The Journal of Biological Chemistry, 277, 4806-4815.

[27] Haemmerle G, Lass A, Zimmermann R, Gorkiewicz G, Meyer C, Rozman J, Heldmaier G, Maier R, Theussl C, Eder S, Kratky D, Wagner E F, Kingenspor M, Hoefler G, Zechner R (2006) Defective lipolysis and altered energy metabolism in mice lacking adipose triglyceride lipase. Science, 312, 734-737.

[28] Holm C, Kirchgessner T G, Svenson K L, Fredrikson G, Nilsson S, Miller C G, Shively J E, Heinzmann C, Sparkes R S, Monandas T. (1988) Hormone-sensitive lipase: sequence, expression and chromosomal localization to 19 cent-9 $9^{13,3}$. Science 241: 1503-1506

[29] Reid BN, Ables GP, Otlivanchik OA, Schoiswohl G, Zechner R, Blaner WS, Goldberg IJ, Schwabe RF, Chua Jr SC, Huang LS. (2008) Hepatic overexpression of hormone-sensitive lipase and adipose triglyceride lipase promotes fatty acid oxidation, stimulates direct release of free fatty acids, and ameliorates steatosis. The Journal of Biological Chemistry, 283 (19), 1308713099.

[30] Xie WH, Sun C, Liu SM. (2009) Effect of hawthorn flavanone on blood-fat and expression of lipogenesis and lipolysis genes of hyperlipoidemia model mouse. Zhongguo Zhong Yao Za Zhi, $\mathbf{3 4}$ (2), 224-229 (in Chinese).

[31] Rosebrough RW, Poch SM. (2002) Dietary protein regulates in vitro lipogenesis and lipogenic gene expression in broilers. Comparative Biochemistry and Physiology, PArt A, Molecular \& Integrative Physiology, 132 (2), 423-431.

[32] Nguyen PL, Ma J, Chavarro JE, Freedman ML, Lis R, Fedele G, Fiore C, Qiu W, Fiorentino M, Finn S, Penney KL, Eisenstein A, Schumacher FR, Mucci LA, Stampfer MJ, Giovannucci E, Loda M. (2010) Fatty acid synthase polymorphisms, tumor expression, body mass index, prostate cancer risk, and survival. Journal of Clinical Oncology, 28 (25), 3958-3964.

[33] Chakravarthy MV, Zhu Y, Yin L, Coleman T, Pappan KL, Marshall CA, McDaniel ML, semenkovich CF. (2009) Inactivation of hypothalamic FAS protects mice from diet-induced obesity and inflammation. Journal of Lipid Research, 50 (4), 630640.

[34] Wu CH, Yang MY, Chan KC, Chung PJ, Ou TT, Wang CJ. (2010) Improvement in high-fat diet-induced obesity and body fat accumulation by a Nelumbo nucifera leaf flavonoid-rich extract in mice. Journal of Agricutural and Food Chemistry, 58, 7075-81.

[35] Kanda T, Brown JD, Orasanu G, Vogel S, Gonzalez FJ, Sartoretto J, Michel T, Plutzky J. (2009) PPARgamma in the endothelium regulates metabolic responses to high-fat diet in mice. The Journal of Clinical Investigation, 119 (1), 110-24.

[36] Mangelsdorf DJ, Thummel C, Beato M, Herrlich P, Schütz G, Umesono K, Blumberg B, Kastner P, Mark M, Chambon P, Evans RM. 1995. The nuclear receptor superfamily: the second decade. Cell, 83 (6), 835-839.

[37] Tontonoz P, Hu E, Graves RA, Budavari AI, Spiegelman BM. (1994) mPPAR gamma 2: tissue-specific regulator of an adipocyte enhancer. Genes \& Development, 8 (10), 1224-1234.

[38] Cho KW, Kim YO, Andrade JE, Burgess JR, Kim YC. (2011) Dietary naringenin increases hepatic peroxisome proliferatorsactivated receptor $\alpha$ protein expression and decreases plasma triglyceride and adiposity in rats. European Journal of Nutrition, 50 (2), 81-88. 
[39] Kim GS, Park HJ, Woo JH, Kim MK, Koh PO, Min W, Ko YG Kim CH, Won CK, Cho JH. (2012) Citrus aurantium flavonoids inhibit adipogenesis through the Akt signaling pathway in 3T3-L1 cells. BMC Complementary and Alternative Medicine, 12, 31-40.

[40] Gong Z, Huang C, Sheng X, Zhang Y, Li Q, Wang MW, Peng L, Zang YQ. (2009) The role of Tanshinone IIA in the treatment of obesity through peroxisome proliferate-activated receptor $\gamma$ antagonism. Endocrinololy, 150 (1), 104-113.

[41] Li RW, Theriault AG, Au K, Douglas TD, Casaschi A, Kurowska EM, Mukherjee R. (2006) Citrus polymethoxylated flavones improve lipid and glucose homeostasis and modulate adipocytokines in fructose-induced insulin resistant hamsters. Life Sciences, 79 (4), 365-373. 